But Prof. Huntley, in his preface, says that the book "is primarily intended for aspirants to University Honours". Personally, I do not think it would be practicable to introduce his subject-matter in so much detail into a crowded university honours course, because, after all, it is only a part of nuclear physics. However, I would encourage any undergraduate or postgraduate student to read the book as part of his all-round education. From this point of view it is perhaps a pity that the author has loaded the book with descriptions of more or less elementary background material (even, surprisingly, of the Michelson-Morley experiment). Such matters are not adequately dealt with from a student textbook point of view and might well have been taken as read. In place, though the author's charts of isotopes are excellent, I would have liked to see the inclusion of a table of all the known nuclei (stable and unstable) such as the Seaborg-Perlman table of isotopes.

In spite of such criticisms, I am sure that Prof. Huntley's book should be on the shelves of all physies libraries, since it undoubtedly contains a great deal of interesting material not available elsewhere in concise form.

H. W. B. SKINNER

\section{SHRUNKEN HEADS}

Amazon Head-Hunters

By Lewis Cotlow. Pp. $208+17$ plates. (London: Robert Hale, Ltd., 1954.) 18s. net.

HE author of this book is a New York insurance broker whose hobby is travelling in lands inhabited by primitive races. $\mathrm{He}$ is an expert photographer, and on his journeys he has sometimes had the aid of professional ciné-photographers. His African film entitled "Savage Splendour" was a success. Between 1940 and 1949 he made several expeditions to the north-west of the South American continent, from which rise the head-waters of the Amazon, and to country farther north around the Isthmus of Panama. These are the areas inhabited by the Choco, Colorado and Yagua Indians, and include also the very isolated country of the Jivaro Indians, who are especially known for their custom of clrying and shrinking the heads of their enemies. The author has prepared commercial films relating to these journeys, and he has lectured much on his experiences. This book gives a connected story and makes most interesting reading. It contains a great deal of first-hand material which is of value to the anthropologist.

While most of the tribes visited by the author are quite 'unspoiled' by contact with civilized peoples, the scientist will no doubt find his most interesting material in the sections which deal with the Jivaro Indians. Mr. Cotlow was able to become very friendly with several of their chiefs, and they informed him of the number of heads which they had taken during their lives. He brings out forcibly the fact that the relatives of a man slain in battle are in honour bound to kill his killer and to shrink-his decapitated head. The relatives of this victim must retaliate in the same manner, so that inter-community warfare is almost continuous. The author describes fully the method of shrinking a head. Unfortunately, he did not actually $s e \theta$ it carried out, since at the time of the raid he was stricken with dysentery. He did see and photograph the victory-dance which followed the exploit. He also describes in detail the making of the fine blow-guns which are used by the Jivaros. $\mathrm{He}$ frequently watched the use of the curare-tipped darts in killing animals. Birds died at once; monkeys survived between two and four minutes. Larger animals were only irritated by these poisonous darts. The author describes the use of the pincers of living ants for the purpose of suturing wounds. He also describes an attack by the tiny, yet much dreaded, canero fish which embeds itself in the natural orifices of the body. His comments on the food of the Indians are illuminating; for example, monkey stew he found not unacceptable, until he noticed a tiny hand floating in it. During one of his trips to the natives he was made a blood-brother of the tribe, and it took him a week to remove the paint.

This interesting and entertaining book is written modestly and without literary embellishment. The author's sympathy with the Indians is apparent on every page. E. AsHwORTH UNDERWOOD

\section{BIOCHEMISTRY OF CANCER}

\section{Biochemistry of Cancer}

By Jesse P. Greenstein. Second edition. Pp. xiii + 653. (Now York : Academic Press, Inc.; London : Auademic Books, Ltd., 1954.) 12 dollars.

CANCER research and biochemistry are both wide I and rapidly growing fields of study, so that Dr. Greenstein has a wealth of material to discuss in this work. He ranges from the study of theoretical chemistry in relation to structure of cancer-producing compounds to the structure of virus particles which can transmit malignant disease and the genetic factors in cancer.

Dr. Greenstein, who is chief of the Laboratory of Biochemistry in the National Cancer Institute, Bethesda, Maryland, performed a most useful service to cancer research workers and biochemists when he published the first edition of this book in 1947. Since then many new facts have been discovered and hypotheses advanced, and these have been incorporated into the new edition by rewriting most of the book. The work is divided into three main sectionsthe induction of cancer; attempts at control of tumour induction and tumour growth; and the properties of tumours.

The processes of induction of cancer by viruses, hormones, hydrocarbons, aromatic amines, aliphatic halogen compounds, metals, alkylating agents and radiations are all considered. The section on control of cancer induction and growth is still the smallest; but it has increased in size relatively much more than the other parts of the book since the first edition. The last section, dealing with the chemistry and biochemistry of tumours and tumour-bearing hosts, occupies about half the book and is the field in which the author has made his own distinguished contributions. This section is unique, as no other modern comparative account of the different properties of tumours is available.

This new edition should be a great help to cancer research workers; it would be even more valuable if the index were more complete and detailed. Biochemists working in fields outside cencer research should find this monograph of interest.

E. Boyland 